\title{
Geography and history education in Estonia: processes, policies and practices in an ethnically divided society from the late 1980s to the early 2000s
}

\author{
JAANUS VEEMAA \& JUSSI S JAUHIAINEN
}

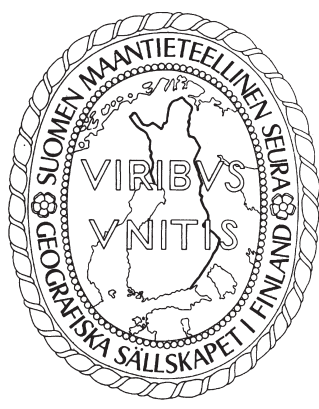

\begin{abstract}
Veemaa, Jaanus \& Jussi S Jauhiainen (2016). Geography and history education in Estonia: processes, policies and practices in an ethnically divided society from the late 1980 s to the early 2000s. Fennia 194: 2, 119-134. ISSN 17985617.
\end{abstract}

This article studies processes, policies and practices for geography and history education in Estonia. The analysis covers the societal transformation period in an ethnically divided society from the 1980s to the early 2000s characterized by Estonia's disintegration from the Soviet Union towards the integration to the European Union and NATO. Geography and history education curricula, textbooks and related policies and practices promoted a particular national timespace by supporting the belongingness of Estonia into Europe, rejecting connections towards Russia and suggesting a division between ethnic Estonians and ethnically non-Estonian residents of Estonia. In geography and history textbooks, the Russian-speaking population, comprising then almost a third of the entire population of Estonia, was divided into non-loyal, semi-loyal and loyal groups of whom only the latter could be integrated in the Estonian time-space. The formal education policies for geography and history supported Estonia's disintegration from the Soviet past and pawed way to integration to the western political and economic structures. However, challenging market and sensitive cultural contexts created peculiar, alternative and sometimes opposing local practices in geography and history education.

Keywords: Estonia, geography and history education, critical discourse analysis, school textbooks, national time-space, education policy

Jaanus Veemaa, Johan Skytte Institute of Political Studies, University of Tartu, Lossi 36, EE-51003, Tartu, Estonia. E-mail: jankaf@ut.ee

Jussi S. Jauhiainen, Department of Geography and Geology, University of Turku, 20014 University of Turku, Finland and Institute of Ecology and Earth Sciences, University of Tartu, Vanemuise 46 EE-50010 Tartu, Estonia. E-mail: jusaja@utu.fi

\section{Introduction}

This article studies processes, policies and practices for geography and history education in Estonia. The analysis covers the societal transformation period from the 1980s to the early 2000s, characterised by Estonia's disintegration from the Soviet Union towards the integration to the European Union (EU) and NATO. The main topic here is Estonia but broader connections from the case can be made as regards many Central Eastern European (CEE) and post-Soviet countries, and other states facing profound social, economic and political transformations.
The five decades long Soviet occupation meant that by the end of 1980s Estonia had become an ethnically divided society. Two-thirds of the population were Estonian-speaking ethnic Estonians and one third was Russian-speaking population consisted of Russians, Ukrainians, and other people. The political context changed when an independent Estonian nation-state was re-established in 1991. In such transformation era, geography and history education and the contexts of related school textbooks became particularly important to reflect the new political reality. For example, Pääbo (2014) has illustrated how the contents of the history school textbooks in Estonia were used to 
support the transition of Estonia from the Russian civilization to the construction of the Baltic Sea region as the Estonian historical space.

The distancing from the former colonizer Russia/Soviet Union required also change in the memory politics of the country and the promotion of specific geographical and historical knowledge. Instead of focussing on the spatio-temporal representation of Estonia through history textbooks as the Estonian master narrative (see Pääbo 2011, 2014), this article opens the complex processes connected to the policies and practices in geography and history education that made possible spatial socialisation, national conciliation and the formation of the post-Soviet Estonian time-space (see Björklund 2004; Rubene 2010). To accomplish this, geography and history are very important topics since in the transformation period in Estonia, like in the CEE countries, the content change priority in education was given to history and geography as well as to civics, ethics, literature and social studies (Cerych 1997: 85). The education of geography and history is often regarded as a central medium in national education through which spatial socialisation is channelled and shared spatio-temporal consciousness imposed in a society (Paasi 1996). To fit in the new context, the falsifications of the former colonizer need to be removed from geography and history education and the white spots need in the school textbooks to be filled and written.

The main research questions of the article are: (1) How state ideology (language policy) and the market economy (textbook publishing business) were involved in the geography and history textbook production processes in Estonia in the transformation years from the late 1980s until the early 2000s? and (2) how social and political integration was discussed in geography and history textbooks in that period? Furthermore, our methodological interest is to find out (3) the contribution of processual use of critical discourse analysis in the study of geography and history education development along societal transformation.

\section{Spatial socialization, education and school textbooks of geography and history}

Geography and history are the cornerstones of nation-building connecting profoundly to strategi- cally planned policies and practices of spatial socialisation (Paasi 1996). Importantly, spatial socialisation highlights the constitutive role of a space and time in building the national identity and framing political developments in society. Spatial socialisation plays a vital role in securing the constitution and continuity of the state and legitimising its policies. This process, by promoting shared spatio-temporal consciousness of society members, also helps to organise and implement control and surveillance over the state territory and its population (Alonso 1994; Brenner 2004; Robertson 2011).

The process of spatial socialisation is usually conducted by means of spatial imaginations. Spatial imaginations are more or less effectively conceptualised and ideologised knowledge about the geography and history of a particular territorial unit, e.g. state, region, etc. The conceptualisation of geographical and historical knowledge is typically built around spatial (e.g. location, place, borders, neighbourhood, scale, relation, affiliation, difference, function, etc.) and temporal (e.g. epoch, period, event, development, process) categories (Veemaa 2014: 12-14). The mediation of spatial imaginations takes place through the techniques of visualisation and story-telling in the form of pictures, charts, maps, and written and spoken narratives (Häkli 2001).

Spatial imaginations are legitimised, communicated, and fostered in society by institutions having power. Besides formal state regulatory authorities, these also include education and the mass media providing viewpoints on particular events, processes and territories. However, spatial imaginations are often contested, and a purely uniform or ideologically ideal collective spatial imagination does not exist in practice (see Smith 1999). The fragmentation of spatial imagination and setbacks in spatial socialisation in general are often characteristic of ethno-culturally divided transitional societies in which nation-building occupies a key place among governmental policies and conciliation between ethnic groups is urgently targeted.

Therefore, the spatial socialisation tends to be particularly challenging in countries experiencing deep societal transformation, or in which the hegemonic state containing many cultures breaks down and new independent states emerge. The state-building in the post-communist Eastern Europe, for example, has rarely been only about rational efficiency with regard to the transformation 
of political and economic regimes. This process has often been exhausted by escalating ethnic conflicts, ideological competitions over national dominance, and vulnerable territorial integrity. In many cases, the confrontation of an oppressor state legacy, including the negative effects of centrally planned migration and long-term cultural antagonisms between ethnic groups, have become an important part of state-building ideology (Smith et al. 1998).

Furthermore, as some scholars have noted, the establishment of independent statehoods in the post-communist Eastern Europe has often been aggregated into 'nationalising' policies. These seek to claim ownership of a state for an ethno-cultural core nation and institutionalise state actions to strengthen the 'unhealthy' condition of the core nation (Brubaker 2011: 1786; cf. Kuzio 2001). Such compensatory policies also tend to be grounded on claims that the identity of a core nation or a specific indigenous population constitutes the identity of a nation-state (Michaels \& Stevick 2009). Therefore, the officially promoted narratives of geography and history are used to support the existence of the nation-state (see also Marsden 2001; Van Sledright 2008). Alternative narratives are often considered by authorities as discreditable to the existence of the nation-state as well as its core nation. The national identity narratives tend to be essential and become exclusionary as regards other than the titular nation (see Feldman 2001). In the end, nations are both political constructs and systems of cultural representations (Solomos 2000: 203).

Scholars have argued that national education systems play a particularly important role in social reproduction and identity politics in the state area, thus contributing to spatial socialisation and statebuilding (Knight 1982; Apple 1996). Education constructs and promotes the central ideologies and the symbolic forms to create an integrated social reality of a given state. It facilitates the inhabitants' learning of common forms of understanding, speaking, and writing, especially concerning culture (Poole 1995).

Newman and Paasi (1998: 196) conceive the "pedagogy of space" as the process through which institutional "discursive landscapes of power" infuse the national space - whether understood as the country's borders or its geographic landscape with certain cultural, social and national meanings. However, Silova et al. (2014) point correctly out that multiple pedagogies of space[s] exist that are sometimes complimentary and other times contradictory but always plural, partial and open to contestation. These pedagogies of space are crucial in the discursive system that builds and maintains a linkage between particular spaces, territories, peoples and cultures.

Geography and history education is important for channelling spatial socialisation and imposing a shared spatio-temporal consciousness in a society (Paasi 1996). In education, the promotion of specific geographical and historical knowledge is a tool for learning and sharing how particular events occurred and things are organised in the national time-space. It also manifests power that is ideologised and conceptualised within national education strategies, curriculum design, textbook production, and teaching practices (Häkli 2001). History teaching tends to focus on intimate emotional adherence to national identity symbols and narratives and to develop a strong and unique emotional bond to it (Carretero 2011: 5).

School textbooks are a key medium through which the selected knowledge about the state territory, people and events is passed to the population. They serve for political and instructional purposes (Williams 2014: 327). Geography and history textbooks are "an expression of societal conditions and represent the 'regimes of truth' that prevail in a society and are employed in the construction and control of its social consciousness" (Paasi 1999: 14).

School textbooks can express different perspectives on the state population. They may try to support the integration of the different ethnic groups living in the state territory, reduce ethno-cultural polarisation and promote national solidarity (Morgan 2003). On the contrary, they may also foster the position of one particular ethnic group, often linked to the construction of the nation-state. According to Williams (2014: 328), the school textbooks, particularly those of geography and history, tend to valorise the nation, simplify the narrative, change the narrative according to changes in the political environment, hide and even mystify the construction and change of narratives, and retain the deepest underlying narrative template. It is common to argue over the memories of the past and to select those memories that are wanted to cherish, repeat or create new ones to successive generations (Van Sledright 2008: 116). In the end, school textbooks are key instruments of spatial imagination and spatial socialization. 


\section{Materials and methods}

The main empirical material consists of all history and geography textbooks regarding Estonia that were produced in Estonia in 1991-2002 and were used in primary and high schools (Rummo 1993a, 1993b; Toomet 1993; Sarapuu 1994a, 1994b; Laur et al. 1995; Laar et al. 1997; Mäesalu et al. 1997; Rummo \& Kont 1999; Tõnisson \& Pihel 1999). This is the empirical material to answer to the second research question, i.e. how social and political integration was discussed in geography and history textbooks? We interpret the meanings of spatial, historical and political imaginations in school textbooks in detail and uncover the ways in which these imaginations become integrated within the social structures in particular places and times.

However, before entering in the details of the textbooks, we also place them and their production in the background context. We contextualize the textbook production through complex communicative events, such as the formation of the titular Estonian nation, official language policy in Estonia, the key education reforms in Estonia and the practices of market economy in 1989-2002. This analysis answers to the first research question, i.e. how state ideology (language policy) and the market economy (textbook publishing business) were involved in the geography and history textbook production processes in Estonia?

For the analysis, we use critical discourse analysis (CDA). CDA is a method to investigate how language, texts and discourses are related to production and reproduction of inequality, power and domination in society, how these are resisted, and how relations of societal power develop. Commonly, CDA is applied through the analysis of texts, discourse practices and socio-cultural practices as discursive events (cf. Fairclough 1995; Van Dijk 2008). In this article, we focus on text production and distribution of school textbooks but have to leave out the important issue of consumption. In our analysis, we stress the importance to approach the context processually. This is the third aim in the article, i.e. to find out the potential contribution of the processual use of CDA to the study of geography and history education development along societal transformation. This means that the notion of discursive event in CDA is extended into processes.

Therefore, we apply CDA to take into account the processual characters of the education policies and practices in the studied transformation period.
For such perspective, it is important to contextualize spatial and temporal changes in society in Estonia and both formal and alternative policies and practices over the period studied from the late Soviet to the EU pre-integration era. Legal frameworks, reform policies and institutional practices of education are central mechanisms through which compatibility between knowledge of the national time-space and effective spatial socialisation and national conciliation are connected (Blommaert \& Bulcaen 2000; Robertson 2011).

We conduct research through four aspects of which the three first elaborate the context for the detailed textbook analysis, e.g. the three firstly mentioned aspects respond to the first research question and the textbook analysis responds to the second research question.

Firstly, the research begins by contextualising the ethno-cultural conditions in Estonia in the transformation period from the late 1980s. The specific focus is on the official state language policy and its role in the Estonian state-building (Estonian Supreme Council 1989; High Council of the Republic of Estonia 1992; National Constituent Assembly 2004 [1938]; see also Järve 2002; Siiner 2006; Hogan-Brun et al. 2008; Brown 2009). In the analysis here, it is important to 'return' to this ethno-political context in which the educational reforms, policies and practices and further geography and history school textbook production took place.

Secondly, we explore the education reform policies and the enactment of the national curricula in geography and history that guided the composition of all school textbooks in Estonian, the official language of the country. We study the reforms in the Estonian education system by analysing relevant legislative acts and educational documents produced in 1991-2002. These include the education-related decrees, such as those of primary and high schools, as well as the National Curriculum (see The Government of Estonia 1996, 2002) and local study curricula regarding geographical and historical education material (see Käosaar 1998; Sulg 1998; Kaldma 2000; Liiber 2000). The CEE countries went through a number of education reforms in the 1990s. In general, key issues were to look for the new core curriculum, reshaping the central control of the curricula and opening the role of teachers and individual schools for curricula reforms (Cerych 1997: 85). Again, it is important to open this context in Estonia. We illustrate the priorities in the educational reforms as well as the legal, ideological, and structural frameworks in the 
production of national historical and geographical knowledge in the Estonian education system.

Thirdly, we examine the institutional practices of geography and history school textbook production (for the Anglo-American context, see Marsden 2001). In addition to the production process, we pay attention to legal and economic power relations in the education system. The state, market, and society formed a triangle in which were included textbook authors, cartographers, editors, official reviewers before publishing permission, publishers as well as the state authorities and education officials related to textbooks, and, finally, also schools, teachers and pupils. Often in the analysis on education one relies only on one framework, thus simplifying the context. For example, analysing only the formal legal framework gives an idealistic picture of the situation in education. Furthermore, the legal (ideal) national education framework often neglects the proper attention to the economic context and local political particularities. As the analysis later illustrates, in the transformation years, alternative and even opposing practices existed in the education forming processes illustrating the complexity of the issue in Estonia. Such complexity does not rise only from different political views but also (market) economy plays a role here.

Fourthly, we analyse spatial imaginations in the geography and history school textbooks in Estonia (see also Berg \& Oras 2000; for history school textbooks, see Pääbo 2014). The imaginations in written texts, pictures, figures, and maps in the school textbooks indicate the institutional practices of knowledge production and are concrete manifestations of geography and history education in their time. We collected data from all history and geography textbooks regarding Estonia that were produced in Estonia in 1991-2002 for primary and high schools. Due to the specific goals of the study, we pay special attention to the arguments regarding the Estonian time-space, ethnic relations in Estonia, and the geopolitical self-determination of Estonia.

\section{Legalising the borders of societal inclusion in post-Soviet Estonia}

The first background context for the later analysis of geography and history textbooks is the official state language policy in Estonia and its role in the
Estonian state-building in the transformation years, in particular creating specific ethno-cultural conditions as discussed below.

After the half century of the Soviet occupation, Estonia's independence was restored on 20 August 1991. In Estonia, as in many post-Soviet countries, the processes of independence and 'return' to the West were linked to the policies of national consolidation. As Kopstein and Reilly (2000) have indicated, geographical proximity to the West exercised a positive influence on transformation in the former communist countries - in Estonian case to Finland, Sweden and even to Germany. However, the changed ethno-linguistic situation in Estonia created a challenge for the re-building of a commonly shared national identity and for achieving the goals of societal integration. Right after the Second World War, over nine out of ten people in Estonia were Estonian speakers. In 1989, Estonian speakers comprised six out of ten people $(61.5$ percent). In the 1990s, about every third (ca. 30 percent) 10-19-year-old resident of Estonia spoke Russian as their mother tongue. Later on, by 2000, the share of ethnic Estonians grew to 68 percent, due to the departure of the Soviet military forces and the large out-migration of Slavic groups (Institute of International Social Studies 2003).

Despite the Soviet era substantially increased the amount of Russian-speakers in Estonia, ethno-linguistic assimilation did not take place. Instead, two separate communities of social communication and collective identity emerged - the Estonianspeakers and the Russian-speakers. Although extensive application of the Soviet language policy in Estonia increased the role of the Russian language in public communication, Estonian never ceased to be the language of tuition for native Estonianspeakers (Järve 2002; Siiner 2006). Russian was a compulsory secondary language in the Estonianspeaking schools to facilitate Estonians' communication with the rest of the Soviet Union citizens, and to impose the Soviet politics of territoriality.

In the transformation period starting from the late 1980s, the ideal was to achieve societal consensus by overcoming strong ethnic-cultural antagonisms, ideological conflicts, social inequality, and problems concerning the citizenship policy (Park 1995). In the late 1980s, the Estonian political elite had two visions regarding the constitution of Estonia's statehood and the nation-building. The more nationally-minded politicians advocated the restoration of the Republic of Estonia according to the principles of its legal continuity (Kask 1994). 
By defining the Soviet occupation as an illegal disruption of the Estonian statehood, this vision also deprived the Soviet-era immigrants from the right to a 'natural' membership in Estonia, and denied their role in the nation (re)building process. The group of other politicians saw the principles of the Estonian statehood more liberally. They acknowledged the illegality of the Soviet regime, but did not support the need for the legal continuity of the Estonian state. Their vision of the newly established Republic of Estonia equated the Soviet-era immigrants politically and legally with the ethnic Estonians, promoting thereby more ethnically balanced policies of nation-building.

However, after independence was secured and the political and security contexts changed, the visions of the major political forces in Estonia became to support the restitution thesis. This fostered the division among Estonian- and Russian-speaking ethnic populations in Estonia. It also created room for particular conceptualized and ideologized knowledge that needed to be promoted through education, in particular in geography and history. The language policy structured power relations in Estonia and contributed to inequalities between Estonian- and Russian-speaking populations.

The countermeasures against the Soviet ethnolinguistic policy had already been executed in the perestroika era in the late 1980s. The usage of the Estonian language was considered an expression of loyalty towards the Estonian independence movement and independent Estonia (Hogan-Brun et al. 2008). In 1989, the Parliament of the Soviet Republic of Estonia ratified the Language Act to frame the society's linguistic legality (Estonian Supreme Council 1989). Estonian became then the only official language in state-level public communication and institutions (see Järve 2002; Brown 2009). This dislodged Russian from the administrative regulation process and made it disappear from the officially supported nation-building. In fact, the ideal of a linguistically and culturally cohesive (Estonian) nation with the Estonian language was seen appealing by the ruling authorities in the new context of independent Estonia. The official language policy legitimized the exclusive role of the Estonian language in the education system. The civic nationalism and multiculturalism promoted by the international agencies were considered unattractive (Hogan-Brun \& Wright 2013: 245).

After the independence of the Republic of Estonia was restored, the Citizenship Law of 1938 was re-established with the Estonian Citizenship Law
(High Council of the Republic of Estonia 1992; see also National Constituent Assembly 2004 [1938]). This was another fundamental act in defining the exclusive ethnic power in the country (Brubaker 2011). The legalisation of Estonian citizenship through restitution of the state was an instrument to define the Russian-speaking minority politically as a foreign population in Estonia (Kask 1994). However, they were granted permission to live and work within Estonian territory. Thus, the legal framework and the related ethno-cultural policies in Estonia performed a crucial role in promoting the ethnic-based nation-building and creating the identity connection between the titular nation and the state territory (Hogan-Brun \& Wright 2013).

\section{Ordering knowledge in a transforming society: the Estonian education system}

The second background context for the later analysis of geography and history textbooks is the Estonian education system and its reforms in the transformation years, especially the enactment of the national curricula in geography and history that guided the composition of all school textbooks, as discussed below. Developing a quality control and steering the education reform and its practices were common challenges in Estonia like in the CEE countries in the 1990s (Cerych 1997: 92).

The separation from the Soviet education system in the late 1980s was important to the Estonian independence movement. The bottom-up social participation of ethnic Estonians strongly supported this. Non-governmental organisations, prestigious local politicians, and teachers directly connected to the autonomy and independence movements were particularly important in reformulating the former Soviet education policy in Estonia. At the same time, local Russian-speaking authorities and education specialists were gradually detached from the educational reform discussions, policy formation, and decision-making for several reasons such as ideological disagreements, language barrier, personal antagonism (Sulg 1998).

The general education reform of 1989 in Estonia officially paved the way for organising and re-conceptualising the National Curriculum for education. This reform was also the first official landmark for erasing the Soviet education ideology regarding knowledge about the geography and history of Estonia (Liiber 2000). The ethno-linguistic legalisa- 
tion of Estonia (Estonian Supreme Council 1989) was intensively connected to the national education system reform. This was fully implemented after the country gained its independence in 1991. The legal framework upon which the new educational system was built excluded from the statelevel educational policy administration anyone who did not know enough Estonian.

In the early 1990s, the state power apparatus became strongly Estonian-oriented (Yiftacel \& Ghanem 2004). The state-level policy makers and education reformers shared this (linguistic) ideology; however, in practice, the profound political and economic changes in Estonia constrained the education reform until the mid-1990s. Instead of a long-term strategy, the ruling process in education was synchronised with concrete, immediate contextual needs and a form of "national spirit" consisted of focus on Estonian culture, geography, history and language (see also Tsai 2002: 230-231). Until 1993, the education policy in Estonia was carried out without clear ideas on how to regulate and control education officially and how to deal with the contested and non-transparent production of knowledge in education. As an example of the latter was the use of school textbooks from the Soviet period in many schools due to the lack of new textbooks and resources to buy them. The first school textbooks in Estonian in geography appeared in 1993 (Rummo 1993a, 1993b) and in history in 1994 (Sarapuu 1994a, 1994b).

To foster production, distribution and consumption of 'appropriate' Estonian-oriented spatial imagination of that time, there was a need of formal regulation of education. Without earlier in-depth experience, the preparation for a profound regulative education system was a learning-by-doing process due to the lack of laws, common education agreements, and definitive visions. The stepby-step reform practice in the education system of the early 1990s meant to compose new, temporally limited study programmes for every school year before the National Curriculum was drafted and approved. They were composed by a limited number of Estonian-minded education specialists and used as general blueprints for new history and geography textbooks. The perspective of the first textbook authors - some of whom active politicians - both in history (see Pääbo 2014: 193-194) and geography focussed on constructing the identity of Estonia with Estonians as the titular nation.

The first National Curriculum to last four years was drafted only in 1996 at the initiative of the
Ministry of Education. Institutions, specialists, and pedagogical practitioners collaborated with this (The Government of Estonia 1996). The curriculum indicated the general principles of education and embraced its educational and developmental aims based on the needs of the Estonian-speaking schools (Kalmus 2004). This document also became the obligatory reference as to what to write in the school textbooks. Therefore the National Curriculum ended the epoch of "ad hoc" organization and formalized what should be in the contents of geography and history textbooks. It did not actually mean a major change since the state ideology and the ideology of the individual authors involved in the textbook production were already rather similar. The education policies that regulated knowledge about the Estonian time-space contributed to the ethnically unbalanced nationbuilding in the post-Soviet Estonia.

Meanwhile the textbooks had become a more challenging issue in the Russian-speaking schools. The high schools in Estonia remained divided by the native languages of their pupils, namely Estonian and Russian, as they had been in the Soviet period. Teachers in these Russian-speaking schools were exempt from the strict principles of the Language Law. They could continue as teachers even without any knowledge of Estonian, and their language of tuition continued to be Russian (Vare 2006). However, since no geography or history textbooks were produced in Estonia in the Russian language in the early 1990s, the Russian-speaking schools lacked new teaching material. Besides the Soviet-era material, even new school textbooks originating from Russia were in use. As discussed in the next chapter, only from 1996 onwards it was allowed to translate geography and history textbooks from Estonian to the Russian language.

As was the case with the preparation of the study programmes in the early 1990s, the preparation of the National Curriculum largely excluded the Russian-speaking education specialists. The curriculum did not pay much attention to the integration issues facing the Estonian education system and society in general. However, the curriculum was not ideologically instructive for textbook authors and school teachers because it defined only what was necessary to present in the educational material and to teach in the schools but it did not prescribe how to write and teach (see Gilbert 1989; Cerych 1997; Kaldma 2000). In addition, the curriculum did not provide concrete means for continuous monitoring on how the cur- 
riculum-related knowledge was promoted and interpreted during the everyday teaching work in schools. The schools were allowed to teach additional courses and topics outside the direct content of the curriculum set by the Ministry of Education. This follows the then common trends of decentralization of education in the CEE countries (Cerych 1997). For example, the Russian-speaking schools in Estonia were allowed to teach Russian culture, history, and geography in greater detail compared to the Estonian-speaking schools. Following this, in the 1990s, the formal knowledge regarding geography and history was produced within divided frameworks both in the Estonianspeaking and in the Russian-speaking schools. First, there was the state level, e.g. the top-down official, obligatory, nationally defined knowledge about geography and history. Second, there were various types of less regulated local-level knowledge that often provided an alternative. However, it often highlighted some locally important details in geography and history and did not provide critical or subversive versions of them.

The less-imposed regulation in education practice and allowing locally varied usage of additional knowledge for geography and history classes meant that indirectly the central education authorities recognised the existence of linguistic and cultural minorities in Estonia. However, such recognition was not free from ideologies. On one hand, the formal National Curriculum (The Government of Estonia 1996) defined the national geography and history as the geography and history of ethnic Estonians - namely indicating the necessary topics to be discussed, e.g. locations and events relevant and related to ethnic Estonians. On the other hand, the curriculum allowed exceptions for the Russian-speaking schools through individual school syllabi.

\section{Political ideologies and economic practices in the production of Estonian school textbooks}

The third background context for the later analysis of geography and history textbooks is formed through the ideologies and institutional practices of geography and history school textbook production in the transformation years, especially legal and economic power relations in the education system, as discussed below.
During the Soviet period in Estonia, the school textbooks for geography and history were mainly translated from Russian or written by local authors following the guidelines of the communist regime. In general, the Soviet school system was centralised and unified to ideologize and politicise education to support the Soviet politics and foster the related ideological education of pupils (Rubene 2010). The education reform in Estonia in 1989 created a strong demand for school textbooks with new ideology. The lack of resources and unorganised market meant that in geography and history there were often only instruction textbooks at hand for teachers.

Along with the development of the educational administrative and institutional system, the educational knowledge production market was opened to private enterprises. Such development was common in the 1990s in many CEE countries (Cerych 1997: 86). However, the 'free' market of textbooks was connected to the state political ideology. As mentioned, school textbooks about the geography and history of Estonia needed the centralised ministerial approval. This was to guarantee formally that the material corresponded with the National Curriculum, i.e. the formal ideological positions of the state (see Leonardo 2003; Morgan 2003). The Minister's decree also allowed schools to purchase such formally guaranteed educational material from the resources allocated in the national budget. Minister of Education Tõnis Lukas who later became an author of a history school textbook - confirmed this centralised position: "With publication of the study reference material, we are now located between two pure models centralisation and the free market. In spite of difficulties, and also of oppression, the Ministry [of Education] does not accept the principal transformation from the centralised to free market system" (Odres 1999).

In the transformation years, especially in the 1990s, the schools in Estonia had very limited budgets. The state authorities provided subsidies to schools to purchase exclusively those textbooks that had been authorised by the Subject Council, the content controlling body appointed by the central authorities. This created a two-directional interest in the school textbook production process. Since the aim of private publishing houses was to create profit, they wanted to produce textbooks that sold well. If the textbook content followed the central authorities' guidelines, then its price was lower in the market due to the state subsidies, and 
the schools afforded purchase it. Therefore, it was in the business interest to produce textbooks that followed the national guidelines. On the other, by directing subsidies to textbooks that followed these guidelines, the central authorities could through related business logics indirectly control that the textbook used in Estonian schools were approved by the content controlling body.

The general character of the National Curriculum, the lack of professional school textbook authors, and the non-transparency in the production of knowledge for geography and history school textbooks freed political interest groups to propagate their ideological standpoints in the textbook contents. However, in practice existed ideological uniformity in the production of geographical and historical knowledge connected to the particular political and economic context of Estonia of the 1990s. The dominant political parties in Estonia shared similar ethnocentric visions about Estonia's time-space.

Even if certain political communities would have pointed out that nationalist overtones existed in geography and history textbooks, the new proposed alternative viewpoints would have been dissolved within the highly articulated and collectively intervened production process of the school textbooks. An alternative content would have created a risk of losing time in preparing the textbook because of the prolonged negotiations with the controlling Subject Council, potential rejection of the textbook draft and re-writing of its contents, and therefore losing economic profit in the textbook business. Therefore, the regulatory practices eliminated the potentially alternative and reactionary voices in the production of educational material (see also Apple \& ChristianSmith 1991). The concrete political circumstances in Estonia in the 1990s and the respective economic market condition made the school textbook production and contents lean on the political context of the time.

Again, the Russian-speaking context had its peculiarities. During the 1990s, no independent publishing or writing of textbooks in Russian existed. The 'free' market of textbooks in Estonia meant in practice that the development of educational material was entirely in the hands of the native Estonian-speaking authors and publishing houses. The exclusion of the Russian-speaking actors from the educational knowledge-producing process was not a formal state-level policy by prohibition but a more subtle political practice. The potential interest by the Russian-language publishers was cooled mostly by means of constraining administrative reasons such as the strict language policy (Estonian Supreme Council 1989; Brown 2009) and the specific requirements of the National Curriculum (The Government of Estonia 1996).

In practice, the discussion about the contents of any proposed Russian-language school textbook would have created rather complex practical situations. For example, because the only official language of the state administration was Estonian, then the proposed text for a school textbook in the Russian language would have had to be translated in advance into Estonian. Furthermore, the various discussion rounds about the contents of the textbook with the education authorities, the content controlling body, and the textbook authors would have needed continuous synchronous translation from Russian to Estonian and Estonian to Russian, etc.

The neglected interest of the state administration in obtaining proper education material in Russian led also to controversies between the official state principles and local education practices. As mentioned, in the early 1990s, the scarcity of school textbooks made in Estonia in the Russian language resulted in the import of textbooks from Russia, including those in geography and history (Käosaar 1998). The then-perceived geopolitical enemy Russia provided the educational material to form the spatio-temporal consciousness of the Russian-speaking minority in Estonia.

This situation began to change in 1996, when the state authorities granted Estonian publishers the opportunity to translate their Estonian-language textbooks into Russian. This created new business opportunities for publishers since a rather large share of pupils spoke Russian. The decision also established the formal control over educational material in Russian in Estonia. However, some technical challenges emerged such as the lack of competent translators, especially regarding geography textbooks.

In general, the reduction of Russia's ideological influence over Russian-speaking pupils and teachers in Estonia was a rather late political manoeuvre. This indicates that there was a lack of properly planned strategy regarding the ethnic-based national consolidation and identity formation in the post-Soviet Estonia. The state authorities soon understood that a forceful monopolisation of the geographical and historical discourses in education would not support the societal integration in Estonia (Kannel 1999). However, the prevailing ethnic 
Estonian discourses continued in geography and history textbooks throughout the transformation years, as discussed later in this article.

\section{National time-space in Estonian school geography and history textbooks}

Throughout the transformation years in the 1990s in Estonia, the ideologies and practices of geography and history education produced through textbooks spatial, historical and political imaginations. These integrated within social structures and contexts of the era to form a new national timespace and contribute to spatial socialisation. In the textbooks, the key conceptual sources used for the argumentation and rhetoric about the particular Estonian time-space were national security priorities and the status of the Russian-speaking minority in the country. The imagination about geography and history of Estonia was built on selective storytelling and visualization of spatiality and temporality: geography consisted of location, border, place and neighbourhood, and history consisted of epoch, event and development (see Veemaa 2014: 12). The geography and history textbook authors, influenced by and contributing to the dominant national ideology, imagined the key topics on the basis of an unpleasant historical experience with the Soviet Union, the dangerous geographical neighbourhood of Russia, and the need to protect Estonian ethno-cultural dominance in Estonia (see Rummo 1993a; Toomet 1993; Sarapuu 1994a; Kont \& Rummo 1999).

The textbooks supported an ethnically divided society with orientalist tones (see Said 1979). By 'we' were depicted ethnic Estonians in Estonia and Estonia in the western world. By 'others' were meant the Russian-speakers in Estonia and Russia as the non-western world. Moreover, the national security issues and status of the Russian-speaking minority were seen as inevitably interdependent. The ethnic division of Estonia was seen necessary resulting in growing power domination and inequality relations between Estonian- and Russianspeakers. The case of Estonia is particular but not at all unique among the post-Soviet states. For example, Janmaat (2005: 2007) has noticed how in Ukraine language has been used as a constituent marker of identity in which Russians have then been differentiated as 'other' in the school history textbooks (Silova et al. 2014).
After Estonia's independence was restored in 1991, criticism of Russia as the successor of the Soviet Union was an effective way to confirm the necessity to withdraw from Russia's sphere of influence (Park 1995). Representing Russia as the main threat to Estonia's security rested upon the fear of a military invasion and a possible re-occupation of the Estonian territory:

"The Estonian-Russian relationship has been in a state of mutual opposition. The Russian understanding of the 'former Soviet countries' and its defence strategy are both hostile towards Estonia. Also, there exists a sort of political movement in Russia that has openly announced its desire to restore the Empire. This is why the first concern of Estonian-Russian relations is the state-level security" (Laur et al. 1995: 147).

This promoted and collectively imagined consciousness of the Eastern threat to Estonia was emphasised by the new location of Estonia on the world map. It connected Estonia to the EU and NATO security spaces (see also Berg \& Oras 2000). Since the mid-1990s, the authors of geography and history school textbooks commonly accepted that Estonia could not be a neutral political actor in the contemporary world. They argued that the sovereignty and peaceful development of Estonia could take place only through intensive cooperation and as-soon-as-possible association with Western structures and their democratic values:

"Due to the sensitive geopolitical location, the most important guarantee of Estonian sovereignty is integration with NATO and the European Union" (Laur et al. 1995: 147).

The security conceptions largely defined the spatial identity of Estonia in relation to the contemporary world system; however, security spaces are dynamic and changing (see also Feldman 2001). Therefore, they are also unstable for grounding the imaginations of national time-space. In geography and history textbooks, the bordering of the Western world was a much more powerful intellectual concept in the building of the spatio-temporal identity of Estonia. The ideas of bordering were influenced and inspired by the world divided by civilisations (Huntington 1993). Based on making cultural differences, this concept reflected how Estonia belonged to the West while Russia did not belong. The Russian empire was a historical mistake as Pääbo (2014: 196) puts it. Such a definition highlighted the 'essential' difference between civilised and democratic Europe (Estonia) and rather 
barbarian and despotic Asia (Russia) (see also Said 1979). It helped to justify the vision that Russia had no grounds to claim any national interests in Europe and that the Russian-speaking minorities were natural aliens in Europe - the latter including Estonia (Mäesalu et al. 1997; Tõnisson \& Pihel 1999). In the 1990s, this vision between the Western and the Eastern civilisations was popular in the Estonian society and also among school textbook writers. It was also often introduced in history textbooks. With an illustration of old castles on the border between Estonia and Russia, the authors of one textbook rhetorically explained how the location makes a difference:

"There are in the world only a few such places where the confrontation and co-existence of civilisations are so dramatically materialised. Already for many centuries, these two castles have stood on the border of Europe and Russia, on the border of East and West" (Adamson \& Valdmaa 1999: 52).

These visions also tried to emphasise Estonia's spatial continuity and its cultural and moral right to belong to the European - namely Western European - space. Such boundary drawing helped to naturalise Estonia's project of "returning to" rather than "arriving in" the Western world (see also Lauristin et al. 1997). It also supported both the ethnocultural perspective based on the ethnic Estonian perspective as the titular nation, as well as the perspective of broader belonging to something called "the European". These become mutually constitutive in geography and history school textbooks (see also Michaels \& Stevick 2009: 242-243). However, Pääbo (2014: 201) also finds that Estonia's 'Europeanness' is constructed through connecting Estonia to Northern Europe (see also Pääbo 2011: 257-259).

The spatial imaginations about the Soviet timespace and geopolitical self-determination in Estonian geography and history school textbooks were not only about the selection of political friends and enemies but also helped to define the desirable ethnic relations and ways of conciliation inside Estonia. As Williams (2014: 327) has noted, when nation-states are reconstituting themselves, there is an emphasis on the ancient roots of the nation and the deep connections between the people of the land and the land of the people.

In the 1990s, the Russian-speaking minority was perceived as a major possible source of conflict with Russia. They were seen crucial in the continu- ing strategic interests of Russia in the Baltic area (Aalto \& Berg 2002). In geography and history textbooks, the Russian-speaking minority was subdivided into disloyal, semi-loyal, and loyal groups. This imaginative articulation was transferred from the mainstream national ideology and was carefully connected to the national security contexts. The ethnic policies of Estonia in the 1990s also shared this viewpoint (Laitin 2003).

In the textbooks, the first group of Russianspeakers was depicted negatively as regards their loyalty to the Republic of Estonia. Especially in the beginning of the 1990s, the state authorities were optimistic about the possible massive out-migration of the Russian-speaking population from Estonia to Russia (Park 1995). The Russian-speaking minority - though making almost a third of the total population - did not have a moral right to be or stay in Estonia. Therefore they should migrate to Russia or to other countries of their origin. In the textbooks, these potential leavers were seen as typical Soviet-era immigrants and foreigners:

"The aliens came also by self-initiative or were called in by friends and relatives who were already living in Estonia. The immigrants were mainly low-qualified workers /.../. They felt comfortable anywhere, and they searched for a better life. Such mentality was dominant among the immigrants" (Laur et al. 1995: 133).

In the national discourse, this "Soviet people" category worked to oppose the old and new situation, i.e. Estonia under the Soviet regime and Estonia as an independent country. By defining the conditions for acceptable members of society, the Russian-speakers were represented as temporary aliens not capable of being citizens in the restored Republic of Estonia (see High Council of the Republic of Estonia 1992; National Constituent Assembly 2004 [1938]). As the following empirical examples indicate, the formalization of the $\mathrm{Na}$ tional Curriculum in 1996 did not actually create a major difference in the contents and tones of geography and history textbooks. There is continuity throughout the transformation years. Furthermore, after 1996 it was possible to translate Estonian geography and history textbooks into Russian and use them in the Russian-speaking schools in Estonia. This created potentially sensitive issues because the Russian-speakers were often characterised as relics of the Soviet occupation creating an obstacle to the successful integration of Estonia into the Western world: 
"After gaining independence, Estonia still had problems with the Soviet legacy, such as Russianspeaking workers, who have a strange cultural background, temperament, and living traditions" (Adamson \& Valdmaa 1999: 204).

The out-migration of the Russian-speaking population was highly welcomed by the Estonian state authorities because it increased the proportion of ethnic Estonians in the country (Laitin 2003). In practice, many left and the birth rate rapidly declined challenging the state's long-term future. Despite this, geography and history textbooks saw unacceptable to reduce the out-migration of the Russian-speaking population. For example, in one geography textbook this relationship was represented as follows:

"During the 1990s the population has drastically decreased in Estonia. In this situation, Estonia needs an active ethnic policy. In order to regulate the population processes effectively, restrictions on [the Russians'] immigration and supporting the [Russians'] out-migration are a necessity" (Tõnisson \& Pihel 1999: 69).

Due to the negatively perceived experience regarding immigrants from the Soviet Union, the immigration topic was very sensitive. In the textbooks, the main division regarding the (potential) immigrants was based on the economic ranking of the possible newcomers' home country. If it was higher than that of Estonia, then these people were generally welcomed to the Estonian society. In practice, however, it was believed that a possible massive immigration to Estonia could only come from undeveloped countries.

The semi-loyal Russian-speakers were the second, and actually the most common depiction in geography and history textbooks. They would live in a separated Russian-speaking community in Estonia, because they could not integrate fully into the Estonian society. They were often presented as anonymous subjects of negation - non-Estonians whose loyalty to the Estonian state should be guaranteed through the national legislation. This dividing concept enabled "our history" to be linked with "our native territory" in the construction of the Estonian time-space. The first sentences from one Estonian history school textbook are very illustrative:

"You live in Estonia. This is the land where your parents and grandparents have lived, and also their parents and grandparents for thousands of years. Our state is called the Republic of Estonia" (Laar et al. 1997: 5).
The third depiction saw possible that selective Russian-speakers could be integrated into the nationally constituted Estonian society. This loyal Russian-speaking minority accepted the rules and laws of the Republic of Estonia, was motivated to learn the Estonian language or already knew it. They were recognised as victims of the Soviet forced migration policy and ready to adapt to the values and norms of the Estonian society ab imo pectore (cf. Hogan-Brun \& Wright 2013). They were ideal for defining the national conciliation through education. However, they were not to be assimilated from above, but rather imagined as people who were capable of connecting their "old, rich Russian cultural identity" to the national identity of the Republic of Estonia. As different but loyal 'others' they could be part of the Estonian national time-space (Rummo 1993b; Toomet 1993; Sarapuu 1994b).

In the state-level integration strategies during the transformation years, only these loyal Russianspeakers were defined as innocent victims of the totalitarian regime(s) and eligible for the national integration policies and the conciliatory process in Estonia. However, unlike in school textbooks, their non-Estonian past and Soviet-related spatial identity was emphasised in the state policies. The status of the Soviet-era immigrants and their Estonianborn descendants was equated to any other new migrants who would settle in Estonia after 1991. They could become members of the Estonian society, but only by obeying laws and certain rules and having command of the Estonian language and culture (Estonian Supreme Council 1989; High Council of the Republic of Estonia 1992). This was also well synchronised with the principles of the Estonian language policy (Estonian Supreme Council 1989), which ignored the pressure to grant linguistic autonomy for the Russian-speakers. It was ruled out that the Soviet-era immigrants would have the legal right to demand their specific time-space in Estonia.

\section{Conclusions}

In this article, we studied how the state ideology and the market economy were involved in the geography and history textbook production processes in Estonia in the transformation years from the late 1980s until the early 2000s. We analysed the discourses regarding social and political integration from the geography and history textbooks of 
that period. We paid especial attention to the Estonian time-space, ethnic relations in Estonia, and the geopolitical self-determination of Estonia.

Geography and history education in Estonia, like in many transforming post-Soviet and CEE countries, played an important role in their national consolidation and identity formation (see Cerych, 1997; Kalmus 2003; Björklund 2004; Janmaat 2005; Brubaker 2011; Pääbo 2014; Silova et al. 2014). Learning the common forms of understanding, speaking, and writing regarding the national time-space and constituting common spatial imaginations are important for spatial socialization in securing the stability of the society and the support for related policies.

As this article demonstrates through the analysis of related texts, discourse practices and socio-cultural practices, the societal transformation contexts and related education processes are often very challenging to produce one collectively shared historical and geographical knowledge for the entire society. Triangulating politics, business and societal development in the analysis of education development processes illustrates well their complexities. Such approach is supported methodologically by the processual use of CDA. This reduces the potentially biased and partial interpretations that may arise from concentrating separately only on the formal education reform policy, textbook production or textbook contents or limiting the analysis on one event or moment.

In the transformation years of Estonia, the state ideology and the market economy were involved in many and sometimes controversial ways in the geography and history textbook production processes. The national education reforms, national curricula and the production of geography and history school textbooks supported the idea of the Estonian nation-state consisted of the Estonian language and culture. The state ideology fostered the ethnic Estonian nation-state through the strict language policy, the market economy through textbook publishing business practices, and the dividing concepts in geography and history textbooks. Alternative views were not allowed emerge in the formal education reforms. Language, texts and discourses produced and reproduced inequality, power and domination in the Estonian society, but created also limited resistance.

However, analysing in detail the development of geography and history education in its contexts, we found that difficult economic situation, curiosities of the market economy driven school text- book production and varied local practices created also controversial outcomes. For example, in the early transformation years, the Russian-speaking schools obtained teaching material directly from Russia, and teachers anyway manoeuvred locally within the nationally set topics. Therefore, the national(ist) vision of education policies did not pass through uniformly in local practices in Estonia, especially in the areas in which the Russian-speaking population was considerable.

From the late 1980s until early 2000s, the formal education policies for geography and history supported Estonia's disintegration from the Soviet past and pawed way to the future integration to the European Union and NATO. In geography and history school textbooks, the discourses of social and political integration supported a uniform imagination about Estonian time-space in which Estonia was a natural part of the Western world, Russia a threat to Estonian sovereignty, and the national identity of the Republic of Estonia equalled the identity of ethnic Estonians. The formal state ideology and the contents of the textbooks were rather similar.

As regards the substantial minority of the Russian-speaking population, comprising then almost a third of Estonia's population, the textbooks divided them into non-loyal, semi-loyal and loyal groups. In the textbook, only the latter could be integrated in the Estonian society enriching the Estonian time-space through their cultural peculiarities. In the state policies, these Russian-speakers could achieve the proper right to stay in Estonia only through formal citizenship policy that requires command of the Estonian language and culture. Multicultural perspectives between ethnic Estonians and other residents of Estonia were not presented or discussed in the school textbooks of geography and history. Therefore, education policies and practices had little chance to form a shared national consciousness and reduce the ethno-linguistic polarisation in the Estonian society.

The transformation years following the Soviet occupation can be labelled as post-colonial, e.g. after the Soviet colonialism. However, in Estonia like in many CEE and post-Soviet states of these years, internal national(ist) policies and practices did not treat the population equally. This is understandable taking into account the context but its acceptability depends on one's political perspective on postcolonialism. Furthermore, the current hostility in Estonia towards potential immigration 
of asylum-seekers and continuous harsh criticism towards Russia are not only linked to the particularities of the Soviet occupation era but also on this transformation period when the Estonian ethnic identity was reformed, partly through geography and history education.

Some scholars such as Kitson (2007) suggest as a policy recommendation that in divided societies, history and geography education should be strategically integrated with the general (re-)conciliatory process, promoted and practically executed within the policy reform discourses. Geography and history education can hardly dramatically change ethno-cultural relations at the societal level. However, they can be effective mechanisms to continue conciliatory processes by treating equally the population living in the state territory and supporting minorities' constitutive place in the national time-space.

\section{ACKNOWLEDGEMENTS}

The authors express their gratitude to the constructive criticism provided by the reviewers of Fennia and recognize the impact of reviewers of other journals. The article was partly funded by the Academy Research project nr 259078.

\section{REFERENCES}

Aalto P \& Berg E 2002. Spatial practices and time in Estonia: from post-Soviet geopolitics to European governance. Space \& Polity 6: 3, 253-270. http://dx.doi.org/10.1080/1356257022000031968.

Adamson A \& Valdmaa S 1999. Eesti ajalugu gümnaasiumile. Koolibri, Tallinn.

Alonso A 1994. The politics of space, time and substance: state formation, nationalism and ethnicity. Annual Review of Anthropology 23, 379-405. http://dx.doi.org/10.1146/annurev. an.23.100194.002115.

Apple M 1996. Cultural politics and education. Teachers College Press, New York.

Apple M \& Christian-Smith L 1991. The politics of the textbook. Routledge, New York.

Berg E \& Oras S 2000. Writing post-Soviet Estonia onto the world map. Political Geography 19: 5, 601-625. http://dx.doi.org/10.1016/S0962-6298(00)00005-6.

Björklund F 2004. Ethnic politics and the Soviet legacy in Latvian post-communist education. Nationalism \& Ethnic Politics 10: 1, 105-134. http://dx.doi.org/10.1080/13537110490450791.

Blommaert J \& Bulcaen C 2000. Critical discourse analysis. Annual Review of Anthropology 29, 449-466. http://dx.doi.org/10.1146/annurev.anthro.29.1.447.
Brenner N 2004. New state spaces. Oxford University Press, Oxford.

Brown K 2009. Market models of language policy: a view from Estonia. European Journal of Language Policy 1: 2, 137-146.

http://dx.doi.org/10.3828/ejlp.2009.4.

Brubaker R 2011. Nationalizing states revisited: projects and processes of nationalization in post-Soviet states. Ethnic and Racial Studies 34: 11, 1785-1814.

http://dx.doi.org/10.1080/01419870.2011.579137.

Carretero M 2011. Constructing patriotism: teaching history and memories in global worlds. Information Age Publishers, Charlotte, NC.

Cerych L 1997. Educational reforms in Central and Eastern Europe: processes and outcomes. European Journal of Education 32: 1, 75-96. http://dx.doi.org/10.2307/1503515.

Estonian Supreme Council 1989. Eesti Nõukogude Sotsialistliku Vabariigi keeleseadus [Language law of the Estonian Soviet Socialist Republic]. ENSV Teataja 4, 60.

Fairclough N 1995. Media discourse. Edward Arnold, London.

Feldman M 2001. European integration and the discourse of national identity in Estonia. National Identities 3: 1, 5-21.

http://dx.doi.org/10.1080/14608940020028466.

Gilbert R 1989. Text analysis and ideology critique of curricular content. In De Castell S, Luke A \& Luke C (eds). Language, authority, and criticism: readings on the school textbook, 61-76. Falmer Press, London.

High Council of the Republic of Estonia 1992. Eesti Vabariigi Ülemnõukogu otsus kodakondsuse seaduse rakendamise kohta [Decision of the High Council of the Republic of Estonia on applying the citizenship law]. Riigi Teataja 7, 175.

Hogan-Brun G, Ozolins U, Ramoniene M \& Rannut M 2008. Language politics and practices in the Baltic States. Current Issues in Language Planning 8: 4, 469-631.

http://dx.doi.org/10.2167/cilp124.0.

Hogan-Brun G \& Wright S 2013. Language, nation and citizenship: contrast, conflict and convergence in Estonia's debate with the international community. Nationalities Papers 41: 2, 240-258. http://dx.doi.org/10.1080/00905992.2012.747502.

Huntington S 1993. The clash of civilizations. Foreign Affairs 72: 3, 22-49.

http://dx.doi.org/10.2307/20045621.

Häkli j 2001. In the territory of knowledge: State-centred discourse and the construction of society. Progress in Human Geography 25: 3, 403-422. http://dx.doi.org/10.1191/030913201680191745.

Institute of International Social Studies 2003. Eesti Inimarengu Aruanne [Human development report of Estonia]. TPÜ Rahvusvaheliste- ja Sotsiaaluuringute Instituut, Tallinn.

Janmaat J 2005. Ethnic and civic conceptions of the nation in Ukraine's history textbooks. European Education 37: 3, 20-37. 
Janmaat J 2007. The ethnic 'other' in Ukrainian history textbooks: the case of Russia and the Russians. Compare: A Journal of Comparative and International Education 37: 3, 307-324.

Järve P 2002. Two waves of language laws in the Baltic States: changes of rationale? Journal of Baltic Studies 33: 1, 78-110. http://dx.doi.org/10.1080/01629770100000221.

Kaldma K 2000. Tagasivaade Minevikku - Erinevad Vaatenurgad. Ajalooõpetaja Käsiraamat. Otsingud, Visioonid, Ideed. Jana Seta, Riga.

Kalmus V 2003. Is interethnic integration possible in Estonia?: Ethno-political discourse of two ethnic groups. Discourse \& Society 14: 6, 667-697. http://dx.doi.org/10.1177/09579265030146001.

Kalmus V 2004. What do pupils and textbooks do with each other? Some methodological problems of research on socialization through educational media. Journal of Curriculum Studies 36: 4, 469-485. http://dx.doi.org/10.1080/00220270310001630670.

Kannel A 1999. Eesti keelab Vene õpikute kasutamise. Eesti Päevaleht. Newspaper article 21.01.1999

Kask P 1994. National radicalization in Estonia: legalization on citizenship and related issues. Nationalities Papers 22: 2, 379-391. http://dx.doi.org/10.1080/00905999408408334.

Käosaar I 1998. Õpikud vene koolis - probleemid ja perspektiivid. In Lauristin M, Vare S, Pedastsaar T \& Pavelson M (eds). Multikultuuriline Eesti: Väljakutse Haridusele, 309-320. Vera II, Tartu.

Kitson A 2007. History education and reconciliation in Northern Ireland. In Cole E (ed). Teaching the violent past: history education and reconciliation, 123-154. Rowman and Littlefield, Lanham, MD.

Knight D 1982. Identity and territory: geographical perspectives on nationalism and regionalism. Annals of the Association of American Geographers 72: 4, 514-531.

http://dx.doi.org/10.1111/j.1467-8306.1982. tb01842.x.

Kont A \& Rummo T 1999. Geograafia 9. klassile. Avita, Tallinn.

Kopstein J \& Reilly D 2000. Geographic diffusion and the transformation of the postcommunist world. World Politics 53: 1, 1-37. http://dx.doi.org/10.1017/S0043887100009369.

Kuzio T 2001. Nationalising states' or nation-building? A critical review of the theoretical literature and empirical evidence. Nations and Nationalism 7: 2, 135-154.

http://dx.doi.org/10.1111/1469-8219.00009.

Laar M, Tilk M \& Hergauk E 1997. Ajalugu 5. Klassile. Avita, Tallinn.

Laitin D 2003. Three models of integration and the Estonian/Russian reality. Journal of Baltic Studies 34: 2, 197-222. http://dx.doi.org/10.1080/01629770300000041.

Laur M, Pajur A \& Tannberg T 1995. Eesti Ajalugu 2. Avita, Tallinn.

Lauristin M, Vihalemm P, Rosengren K \& Weibull L (eds) 1997. Return to the Western world. Cultural and political perspectives on the Estonian postcommunist transition. Tartu University Press, Tartu. Leonardo Z 2003. Discourse and critique: outlines of a post-structuralist theory of ideology. Journal of Education Policy 18: 2, 203-214. http://dx.doi.org/10.1080/0268093022000043038.

Liiber Ü 2000. Eesti Üldhariduskooli Geograafia Ainekava ja selle Rakendamine Ôpikutes. Master thesis. University of Tartu, Tartu.

Marsden W 2001. The school textbook: geography, history, and social studies. Woburn Press, Portland, OR.

Mäesalu A, Lukas T, Laur M \& Tannberg T 1997. Eesti Ajalugu 1. Avita, Tallinn.

Michaels D \& Stevick D 2009. Europeanization in the 'other' Europe: writing the nation into 'Europe' education in Slovakia and Estonia. Journal of Curriculum Studies 41: 2, 225-245.

http://dx.doi.org/10.1080/00220270802515919.

Morgan J 2003. Imagined country: national environmental ideologies in school geography textbooks. Antipode: A Radical Journal of Geography 35: 3, 444-462.

http://dx.doi.org/10.1111/1467-8330.00334.

National Constituent Assembly 2004 [1938]. The Constitution of the Estonian Republic. <http:// www.hot.ee/evp 1938/constitution 1938.htm> 20.01.2014.

Newman D \& Paasi A 1998. Fences and neighbours in the postmodern world: boundary narratives in political geography. Progress in Human Geography 22: 2, 186-207.

http://dx.doi.org/10.1191/030913298666039113.

Odres E 1999. Kirjastuste konkurents toob paremad õpikud. Postimees. Newspaper article 18.11.1999.

Paasi A 1996. Territories, boundaries and regional identity. The changing geographies of the FinnishRussian border. John Wiley \& Sons, New York.

Paasi A 1999. Nationalizing everyday life: individual and collective identities as practice and discourse. Geography Research Forum 19, 4-21.

Park A 1995. Russia and Estonian security dilemmas. Europe-Asia Studies 47: 1, 27-45. http://dx.doi.org/10.1080/09668139508412243.

Poole R 1995. Nationalism: the last rites? In Pavcović A, Koscharsky H \& Czarnota A (eds). Nationalism and postcommunism. A collection of essays, 5168. Ashgate, Aldershot.

Pääbo H 2011. Estonian transformation. From an eastern outpost in the West to a western outpost in the East. In Törnquist-Plewa B \& Stala K (eds). Cultural transformations after communism. Central and Eastern Europe in focus, 253-279. Nordic Academic Press, Lund.

Pääbo H 2014. Constructing historical space: Estonia's transition from the Russian civilization to the Baltic Sea region. Journal of Baltic Studies 45: 2, 187-205.

http://dx.doi.org/10.1080/01629778.2013.846929.

Robertson S 2011. The new spatial politics of (re)bordering and (re)ordering the state-education-citi- 
zen relation. International Review of Education 57: 3-4, 277-297. http://dx.doi.org/10.1007/s11159-011-9216-x.

Rubene A 2010. Topicality of critical thinking in the post-Soviet educational space. European Education 41: 4, 24-40.

http://dx.doi.org/10.2753/EUE1056-4934410402.

Rummo T 1993a. Eesti Geograafia 6. Klassile. Koolibri, Tallinn.

Rummo T 1993b. Läänemeremaade geograafia 9. Klassile. Avita, Tallinn.

Rummo T \& Kont A 1999. Geograafia. Maa ja ilm. 9. Klassile. Avita, Tallinn.

Said E 1979. Orientalism. Verso, London.

Sarapuu J 1994a. Eesti ajaloo algõpetus 1. Õpik põhikoolile. Kiir, Viljandi.

Sarapuu J 1994b. Eesti ajaloo algõpetus 2. Õpik põhikoolile. Kiir, Viljandi.

Siiner M 2006. Planning language practice: a sociolinguistic analysis of language policy in post-communist Estonia. Language Policy 5: 2, 161-186. http://dx.doi.org/10.1007/s10993-006-9004-9.

Silova I, Mead Yaqub M \& Palandjian G 2014. Pedagogies of space: (re)mapping national territories, borders, and identities in post-Soviet textbooks. In Williams J (ed). (Re)Constructing memory: school textbooks and the imagination of the nation, 103130. Sense Publishers, Boston.

Smith A 1999. Myths and memories of the nation. Blackwell, Oxford.

Smith G, Law V, Wilson A, Bohr A \& Allworth E 1998. Nation-building in the post-Soviet borderland: the politics of national identities. Cambridge University Press, Cambridge.

Solomos J 2000. Race, multi-culturalism and difference. In Stevenson N (ed). Culture \& citizenship, 198-211. Sage, London.

Sulg Ü 1998. Muulaste Integreerimine Eesti Ühiskonda Läbi Hariduspoliitiliste Valikute. Bachelor thesis. University of Tartu, Tartu.
The Government of Estonia 1996. Eesti põhi- ja üldhariduse riiklik õppekava [National curriculum of basic and general education of Estonia]. <https:// $w w w . r i i g i t e a t a j a . e e / a k t / 23657>06.01 .2014$.

The Government of Estonia 2002. Eesti põhi- ja üldhariduse riiklik õppekava [National curriculum of basic and general education of Estonia]. Riigi Teataja 20, 116.

Toomet T 1993. Me elame ajaloos. Eesti ajalooõpik 5. Klassile. Koolibri, Tallinn.

Tõnisson A \& Pihel P 1999. Eesti ja Euroopa. Loodusja inimgeograafia 9. Klassile. Koolibri, Tallinn.

Tsai C 2002. Chinese-ization and the nationalistic curriculum reform in Taiwan. Journal of Education Policy 17: 2, 229-243. http://dx.doi.org/10.1080/02680930110116552.

Van Dijk T 2008. Discourse and power. Palgrave, Houndsmills.

Van Sledright B 2008. Narratives of nation-state, historical knowledge, and school history education. Review of Research in Education 32: 1, 109-146. http://dx.doi.org/10.3102/0091732X07311065.

Vare S 2006. Vene koolide valmisolekust üleminekuks eesti õppekeelega gümnaasiumile 2007. aastal. Eesti Rakenduslingvistika Ühingu Aastaraamat 2, 303-326.

Veemaa J 2014. Reconsidering geography and power: policy ensembles, spatial knowledge, and the quest for consistent imagination. Dissertationes Geographicae Universitatis Tartuensis 56. University of Tartu, Tartu

Williams J 2014. School textbooks and the state of the state. In Williams J (ed). (Re)Constructing memory: school textbooks and the imagination of the nation, 327-335. Sense Publishers, Boston.

Yiftacel O \& Ghanem A 2004. Understanding 'ethnocratic' regimes: the politics of seizing contested territories. Political Geography 23: 6, 647-676. http://dx.doi.org/10.1016/j.polgeo.2004.04.003. 